\title{
"Desenvolvimento de blendas de amido/gelatina adicionadas de extrato de cúrcuma e reticuladas com ácido cítrico"
}

Aguilar, Guilherme José. Desenvolvimento de blendas de amido/gelatina adicionadas de extrato de cúrcuma e reticuladas com ácido cítrico. 2019.151p. Dissertação (Mestrado) Faculdade de Filosofia, Ciências e Letras de Ribeirão Preto, Universidade de São Paulo, Ribeirão Preto, 2019.

\section{RESUMO}

A gelatina e o amido são dois polímeros amplamente aplicados no desenvolvimento de filmes biodegradáveis. Neste trabalho foram produzidas e caracterizadas blendas de amido de mandioca/gelatina adicionadas de extrato de cúrcuma e/ou reticulados com ácido cítrico a fim de avaliar os seus efeitos sobre as propriedades mecânicas e funcionais dos filmes. O efeito da proporção de amido e gelatina nas blendas G/A (90/10, 70/30, 50/50, 30/70 e 10/90) sobre as propriedades dos filmes também foram avaliadas. Os filmes de amido (0/100) e gelatina (100/0) pura também foram produzidos para efeitos de comparação com as blendas. O glicerol foi usado como plastificante. Os filmes com uma maior proporção de gelatina na blenda apresentaram maiores valores de tensão e elongação na ruptura, enquanto que aqueles com uma maior proporção de amido foram menos solúveis e menos permeáveis ao vapor de água. Uma concentração igual dos polímeros (50/50) rendeu filmes com aparente separação de fases, pois apresentaram pobres propriedades mecânicas e funcionais, sendo considerada uma concentração crítica na produção das blendas G/A. A adição de extrato de cúrcuma e sua concentração também afetaram as propriedades mecânicas e funcionais das blendas. A reticulação com ácido cítrico melhorou a interação da gelatina e do amido no filme e a dispersão dealta concentração de extrato de cúrcuma (10\%)dentro da matriz da blenda, inclusive em aquelas com maior concentração de amido. Isto permitiu obter filmes menos permeáveis ao vapor de água,menos molháveis em água, porém mais elongáveis quando comparado com os filmes não reticulados e não adicionados de extrato de cúrcuma. A blenda gelatina/amido controles não apresentaram atividade antimicrobiana, enquanto que a blenda gelatina/amido reticulada com ácido cítrico e adicionadas de $10 \%$ de extrato de cúrcuma tevea atividade antimicrobiana contra os microrganismos $S$. agalactiae, $S$. uberise e $S$. aureus.

PALAVRAS-CHAVE: blendas, filmes biodegradáveis, reticulação, ácido cítrico, antioxidante, antimicrobiano, gelatina, amido, extrato de cúrcuma. 
Aguilar, Guilherme José. Development of starch/gelatin blends added with turmeric extract and crosslinked with citric acid.2019.151 p. Dissertação (Mestrado) - Faculdade de Filosofia, Ciências e Letras de Ribeirão Preto, Universidade de São Paulo, Ribeirão Preto, 2019.

\begin{abstract}
Gelatin and starch are two polymers widely applied in the development of biodegradable films. In this work, cassava starch / gelatin mixtures added with turmeric extract and/or crosslinked with citric acid were produced and characterized in order to evaluate their effects in the mechanical and functional properties of the films. The effect of the proportion of starch and gelatin on the G/A blends (90/10, 70/30, 50/50, 30/70 and 10/90) in the film properties were also evaluated. Starch $(0 / 100)$ and gelatin $(100 / 0)$ pure films were also produced for comparison purposes with the blends. Glycerol was used as a plasticizer. The films with a higher proportion of gelatine in the blends showed higher tensile values and elongation at break, whereas those with a higher proportion of starch were less soluble and less permeable to water vapor. An equal concentration of the polymers (50/50) yielded films with apparent phase separation, since they presented poor mechanical and functional properties, being considered a critical concentration in the production of G/A blends. The addition of turmeric extract and its concentration also affected the mechanical and functional properties of the blends. Crosslinking improved the interaction of gelatin and starch and the high concentration dispersion of turmeric extract $(10 \%)$ within the blend matrix, even in those with higher starch concentration. This allowed to obtain films less permeable to water vapor and with less wettability in water and more elongable when compared to non-crosslinked films and not added turmeric extract. The gelatin/starch blends showed no antimicrobial activity, whereas the gelatin / starch blend with the addition of $10 \%$ turmeric extract induced antimicrobial activity against the $S$. agalactiae, $S$. uberis and $S$. aureus microorganisms.
\end{abstract}

KEYWORDS: blends, biodegradable films, cross-linking, citric acid, antioxidant, antimicrobial, gelatin, starch, turmeric extract. 


\section{INTRODUÇÃO}

Um filme biodegradável trata-se de um material de espessura fina produzido a partir de polímeros biodegradáveis que também podem ser comestíveis (desejável). O filme biodegradável pode ser usado como embalagem em alimentos, cuja função é proteger o alimento contra agentes mecânicos e biológicos, e consequentemente aumentar o seu tempo de vida útil. Estes materiais tem ganhado muito interesse na comunidade científica por ser uma alternativa para diminuir o grande consumo de plásticos sintéticos, que devido ao seu maior tempo de degradação (>100 anos) acumulam-se no meio ambiente.

Os filmes biodegradáveis geralmente são produzidos a partir de polissacarídeos, lipídeos, proteínas e outros. A sua obtenção é baseada na dispersão e solubilização dos biopolímeros em um solvente, acrescentando aditivos (como plastificantes) e gerando uma solução filmogênica (HENRIQUE; CEREDA; SARMENTO, 2008), a qual é aplicada no molde de interesse ou no produto (coberturas) e são secas, gerando filmes ou coberturas filmogênicas pelo método tipo casting (GONTARD; GUILBERT; CUQ, 1992).

O amido é um polissacarídeo altamente hidratável devido aos seus grupos hidroxilas, que formam ligações de hidrogênio com moléculas de água. Sua função é de armazenamento de energia e grande parte das células vegetais possui a capacidade de sintetizá-lo. É especialmente abundante em tubérculos e grãos (COX; NELSON,2006). O amido de mandioca tem sido amplamente utilizado para produção de filmes e blendas biodegradáveis devido ao seu baixo custo, boa estabilidade do gel e também à baixa temperatura de gelatinização (MALI et al., 2006, FAKHOURY et al., 2012).

Filmes produzidos a partir de amidos são geralmente muito hidrofílicos, mas possuem a vantagem de ser um recurso barato e renovável (BOURTOOM, 2008). A aplicação do filme de amido é limitada devido ao fato de sua alta solubilidade, hidrofilicidade e fragilidade. A fim de amenizar esta deficiência, alguns autores tem proposto a formação de blendas com proteínas, acarretando na diminuição da permeabilidade ao vapor de água e aumentando a sua força de tensão (KIM; HANNA; NAG, 2005). 
A blenda polimérica é o produto resultante da mistura mecânica de dois ou mais polímeros. A produção de blendas poliméricas podem melhorar as propriedades específicas dos filmes quando comparamos com filmes puros. A escolha do par polimérico para a produção de uma blenda obedece principalmente os critérios relacionados ao custo, propriedades e processabilidade (NUNES, 2014). Blendas poliméricas produzidas a partir de amido e gelatina geraram resultados satisfatórios, mostrando melhores propriedades de barreira para gases quando comparados aos filmes puros (FAKHOURY et al., 2012, ZHANG et al., 2013, AL-HASSAN; NORZIAH, 2017). Entretanto, quando se altera a proporção de cada par polimérico tem-se influência nas propriedades mecânicas, físicas e na permeabilidade ao vapor de água das blendas (ALHASSAN; NORZIAH, 2012).

A gelatina é derivada do colágeno, através de desnaturação química, obtido de ossos, pele e tecido conjuntivo que são resíduos no abate animal e no processamento da carne (NUR HANANI; ROOS; KERRY, 2014). Filmes gerados a partir de gelatina são mais resistentes a solventes e também possuem melhores propriedades em relação à permeabilidade ao oxigênio quando comparados aos filmes de amido (NUR HANANI; ROOS; KERRY, 2014; WANG et al., 2007).

Outra estratégia utilizada para melhorar as propriedades mecânicas e funcionais dos filmes e blendas biodegradáveis é o processo de reticulação química (REDDY; YANG, 2010; RAMIREZ et al., 2017). Nesse sentido, o ácido cítrico pode ser utilizado como um agente reticulante, conduzindo a formação de ligações cruzadas entre as cadeias polímericas e também formando ligações de hidrogênio com os grupos hidroxilas dos polímeros. A vantagem de usar ácido cítrico como agente reticulantes é a formação de filmes comestíveis e bioativos, principalmente com atividade antimicrobiana.

Uma embalagem bioativa é um termo que é utilizado para referenciar embalagens que interagem com o alimento de forma benéfica, apresentando em sua composição materiais de origem biológica e possibilitando a inclusão de prebióticos, probióticos, fitoquímicos, entre outros (ALMEIDA et al, 2015). Diversos estudos foram realizados avaliando a capacidade antioxidante de filmes bioativos como filmes adicionados de extrato de alecrim (PIÑEROS-HERNANDEZ et al., 2017), groselha indiana (SUPPAKUL et al, 2016), óleos essenciais de lavanda e orégano (MARTUCCI et al, 2015), goma de Hsian-tsao (YANG et al., 2015), extrato de chá verde (GIMÉNEZ et al., 
2013), extrato de cacau (CALATAYUD et al., 2013) e curcumina ((BITENCOURT et al., 2014; LIU et al., 2016; MANIGLIA et al., 2014, 2015).

A Curcuma longa é um arbusto perene originário da Índia. A partir de seu rizoma é produzido o pigmento de cúrcuma, que é composto de curcuminóides, principalmente de curcumina, responsável pela cor amarelada do rizoma. A curcumina é um composto polifenólico aromático com propriedade antioxidante e é um dos principais componentes do rizoma da Curcuma longa. (SUETH-SANTIAGO et al., 2015). A curcumina mostra potencial terapêutico contra uma ampla gama de doenças como: diversos tipos de câncer, diabetes, obesidade, cardiomiopatia, bronquite, asma, depressão e doença de Alzheimer (PRASAD et al.,2014). A adição de extrato de cúrcuma em filmes biodegradáveis, pode agregar propriedades bioativas, em destaque a sua capacidade antioxidante (BITENCOURT et al., 2014; LIU et al., 2016; MANIGLIA et al., 2014, 2015).

Diante de todo o exposto, este trabalho teve como objetivo produzir e caracterizar filmes de blendas de amido de mandioca e gelatina adicionadas ou não de extrato de cúrcuma e/ou reticulados com ácido cítrico, avaliando o efeito das proporções dos polímeros, da concentração de extrato de cúrcuma e da reticulação química sobre as propriedades dos filmes de blenda gelatina/amido.

\section{CONCLUSÃO}

A produção de blendas gelatina/amido permitiu a formação de filmes bioativos usando alta proporção de amido e alto teor de curcumina (10\%). Como o amido é um polímero hidrofílico, a dispersão de altas concentrações de curcumina na matriz do filme de amido não foi possível totalmente pela sua característica hidrofóbica, mas quando foi adicionada gelatina na matriz do filme, mesmo em baixas concentrações (10\%) obtevese uma boa dispersão da curcumina na blenda e filmes com boas propriedades funcionais e alta atividade antioxidante. A reticulação com ácido cítrico permitiu obter filmes G/A menos solúveis, menos permeáveis e menos resistentes mecanicamente, porém mais molháveis e mais elongáveis quando comparado com os filmes da blenda controle. As propriedades ópticas dos filmes de blenda G/A não foram muito afetadas pela reticulação com ácido cítrico, mas a adição de extrato de cúrcuma afetou significativamente a coloração dos filmes, tornando os filmes mais amarelados e mais opacos principalmente quando utilizado altas concentrações de amido na blenda G/A. Com a adição de extrato de cúcuma nas blendas reticuladas com ácido cítrico, os filmes tornaram-se menos 
molháveis e menos permeáveis ao vapor de água, porém menos resistentes mecanicamente, pois a elongação do filme aumentou significativamente. As blendas G/A 30/70 e 10/90 reticuladas com ácido cítrico e adicionadas de 10\% de EC formaram filmes com interessantes propriedades funcionais e bioativas para serem usados como cobertura em alimentos. Foi observado um efeito sinérgico entre o ácido cítrico e a curcumina, evidenciando uma possível atividade antimicrobiana, com destaque paea os microrgsanismos $S$. agalactiae, S. uberis e $S$. aureus.

\section{REFERÊNCIAS BIBLIOGRÁFICAS}

ABRE.

Embalagens.

Disponível

em:

$<$ http://www.abre.org.br/setor/apresentacao-do-setor/a-embalagem/>. Acesso em: 2 nov. 2017.

ABRE. Tipos de embalagens. Disponível em: $<$ http://www.abre.org.br/setor/apresentacao-do-setor/a-embalagem/tipos-deembalagens/>. Acesso em: 2 nov. 2017.

ADILAH, A. N. et al. Utilization of mango peel extracts on the biodegradable films for active packaging. Food Packaging and Shelf Life, v. 16, p. 1-7, 1 jun. 2018.

AGGARWAL, B. B.; KUMAR A.; BHARTI. A. C. Anticancer potential of curcumin: preclinical and clinical studies. Anticancer research, v. 23, n. 1/A, p. 363398, 2003.

AGGARWAL, B. B.; SURH, Young-Joon; SHISHODIA. The molecular targets and therapeutic uses of curcumin in health and disease. Springer Science \& Business Media, Shishir, 2007.

AGGARWAL, B. B.; TAKADA, Y.; OOMMEN, V. From chemoprevention to chemotherapy: common targets and common goals. Expert opinion on investigational drugs, v. 13, n. 10, p. 1327-1338, 2004.

AHMAD, M. et al. Physico-mechanical and antimicrobial properties of gelatin film from the skin of unicorn leatherjacket incorporated with essential oils. Food Hydrocolloids, v. 28, n. 1, p. 189-199, 1 jul. 2012. 
AHMED, I. et al. A comprehensive review on the application of active packaging technologies to muscle foods. Food Control, 2017.

AI, Y. F.; JANE, J. Understanding Starch Structure and Functionality. In: Sjöö, M.; Nilsson L. Starch in Food: Structure, Function and Applications. 2 ed. Woodhead Publishing Series. 2018. cap. 3. p. 151-178.

AKCELRUD, Leni. Fundamentos da ciência dos polímeros. Editora Manole Ltda, 2007, 288 p.

AL-HASSAN, A. A.; NORZIAH, M. H. Effect of transglutaminase induced crosslinking on the properties of starch/gelatin films. Food Packaging and Shelf Life, v. 13, p. $15-19$, 1 set. 2017.

AL-HASSAN, A. A.; NORZIAH, M. H. Starch-gelatin edible films: Water vapor permeability and mechanical properties as affected by plasticizers. Food Hydrocolloids, v. 26, n. 1, p. 108-117, 1 jan. 2012.

ALI, M. S. et al. Mucoadhesive microparticulate drug delivery system of curcumin against Helicobacter pylori infection: Design, development and optimization. Journal of advanced pharmaceutical technology \& research, v. 5, n. 1, p. 48, 2014.

ALMEIDA, A. C. S.; FRANCO, E. A. N.; PEIXOTO, F. M.; PESSANHA, K. L. F.; MELO, N. R. Aplicação de nanotecnologia em embalagens de alimentos.Polímeros, São Carlos, v. 25, n. spe, p. 89-97, 2015.

AMASS, W.; AMASS, A.; TIGHE, B. A review of biodegradable polymers: uses, current developments in the synthesis and characterization of biodegradable polyesters, blends of biodegradable polymers and recent advances in biodegradation studies. Polymer international, v. 47, n. 2, p. 89-144, 1998.

American Society for Testing and Materials - ASTM.Standard test method for measure content of paper and paperboard by oven drying- D 664-94. Annual book of ASTM, Philadelphia: ASTM, 1994. 
American Society for Testing and Materials - ASTM.Standard test method for tensile properties of thin plastic sheeting - D 882-95. Annual book of ASTM, Philadelphia: ASTM, 1995.

American Society for Testing and Materials - ASTM.Variability of Water Vapor Transmission Rates of Extruded Polystyrene.ASTM 96-80 (Desiccant Method). Annual book of ASTM, Philadelphia: ASTM, 1989.

ANAND, P. et al. Biological activities of curcumin and its analogues (Congeners) made by man and Mother Nature. Biochemical Pharmacology, v. 76, n. 11, p. 15901611, 1 dez. 2008.

ANGUMEENAL, A. R.; VENKAPPAYYA, D.An overview of citric acid production. LWT-Food Science and Technology, v. 50, n. 2, p. 367-370, 2013.

APEDA.Turmeric.[S.I.], $2005 . \quad$ Disponível em: $<$ http://agriexchange.apeda.gov.in/Market\%20Profile/one/TURMERIC.aspx >. Acesso em 12 jul. 2017.

ARAUJO, C. A. C.; LEON, L. L. Biological activities of Curcuma longa L. Mem. Inst. Oswaldo Cruz, Rio de Janeiro, v. 96, n. 5, p. 723-728, July 2001.

ARVANITOYANNIS, I. et al. Edible films made from gelatin, soluble starch and polyols, Part 3. Food Chemistry, v. 60, n. 4, p. 593-604, 1 dez. 1997.

AVELLA, M. et al. Biodegradable starch/clay nanocomposite films for food packaging applications. Food Chemistry, v. 93, n. 3, p. 467-474, 1 dez. 2005.

AVELLA, Maurizio et al. Polymer-Based Nanocomposites for Food Packaging Applications. Bio-Nanotechnology: A Revolution in Food, Biomedical and Health Sciences, p. 212-226, 2013.

AVEROUS, L. et al. Properties of thermoplastic blends: Starch-polycaprolactone. Polymer, v. 41, n. 11, p. 4157-4167, 1 maio 2000.

AZEREDO, H. M. C. DE; FARIA, J. DE A. F.; AZEREDO, A. M. C. DE. Embalagens ativas para alimentos. Ciência e Tecnologia de Alimentos, v. 20, n. 3, p. 337-341, dez. 2000. 
AZEREDO, H. M. C. et al. Wheat straw hemicellulose films as affected by citric acid. Food Hydrocolloids, v. 50, p. 1-6, 1 ago. 2015.

BAGULEY, R; MCDONALD, C. Appliance Science: The firm chemistry of gelatin. 2015. Disponível em: $<$ https://www.cnet.com/news/appliance-science-the-firmchemistry-of-gelatin/>. Acessado dia 12 de novembro de 2018.

BAKRY, N. F.; ISA, M. I. N.; SARBON, N. M. Effect of sorbitol at different concentrations on the functional properties of gelatin/carboxymethyl cellulose (CMC)/chitosan composite films. International Food Research Journal, v. 24, n. 4, p. $1753,2017$.

BASIAK, E.; LENART, A.; DEBEAUFORT, F. Effect of starch type on the physico-chemical properties of edible films. International Journal of Biological Macromolecules, v. 98, p. 348-356, 1 maio 2017.

BENJAKUL, S.; KITTIPHATTANABAWON, P. Gelatin.Reference Module in Food Science, 1 jan. 2018.

BERNABÉ-PINEDA, M. et al. Determination of acidity constants of curcumin in aqueous solution and apparent rate constant of its decomposition.Spectrochimica Acta Part A: Molecular and Biomolecular Spectroscopy, v. 60, n. 5, p. 1091-1097, 1 abr. 2004.

BITENCOURT, C. M.; FÁVARO-TRINDADE, C. S.; SOBRAL, P. J. A.; CARVALHO, R. A. Gelatin-based films additivated with curcuma ethanol extract: Antioxidant activity and physical properties of films. Food Hydrocolloids, v. 40, p. 145$152,2014$.

BJÖRCK, I. et al. Food properties affecting the digestion and absorption of carbohydrates. The American journal of clinical nutrition, v. 59, n. 3, p. 699S-705S, 1994.

BOURTOOM, T. Edible films and coatings: characteristics and properties.Int. Food Res. J., v. 15, p. 237-248, 2008. 
BOURTOOM, T.; CHINNAN, M. S. Preparation and properties of rice starchchitosan blend biodegradable film. LWT - Food Science and Technology, v. 41, n. 9, p. 1633-1641, 1 nov. 2008.

BRAND-WILLIAMS; W., CUVELIER; M. E.; BERSET, C. Use of a free radical method to evaluate antioxidant activity.Lebensm.Wiss.Technol, v. 28, p. 25-30, 1995.

CALATAYUD, M.; LÓPEZ-DE-DICASTILLO, C.; LÓPEZ-CARBALLO, G.; VÉLEZ, D.; HERNÁNDEZ MUÑOZ, P.; GAVARA, R. Active films based on cocoa extract with antioxidant, antimicrobial and biological applications. Food Chemistry, v. 139(1), p. 51-58, 2013.

CAO, N.; YANG, X.; FU, Y. Effects of various plasticizers on mechanical and water vapor barrier properties of gelatin films. Food Hydrocolloids, v. 23, n. 3, p. 729735, 1 maio 2009.

CARVALHO, W.et al. Aditivos alimentares produzidos por via fermentativa parte I: ácidos orgânicos. Revista Analytica, v. 18, p. 70-76, 2005.

CECILIO FILHO, A. B. et al. Cúrcuma: planta medicinal, condimentar e de outros usos potenciais. Ciência Rural, v. 30, n. 1, p. 171-177, mar. 2000.

CECÍlIO FILHO, A. B. et al. Época e densidade de plantio na produção de cúrcuma. Ciência Rural, v. 34, n. 4, p. 1021-1026, ago. 2004.

CHASSAGNEZ, A. L. M.; CORREA, N. C. F.; MEIRELES, M. A. A.Extração de oleoresina de cúrcuma (curcuma longa $l$ ) com $\mathrm{CO}^{2}$ supercrítico. Ciênc. Tecnol. Aliment. Campinas, v. 17, n. 4, p. 399-404, Dec. 1997.

CIRIMINNA, R. et al. Citric acid: emerging applications of key biotechnology industrial product. Chemistry Central Journal, v. 11, n. 1, p. 22, 2017.

DA SILVA JUNQUEIRA, M.et al. Efeito de embalagens ativas no escurecimento enzimático de batatas (Solanum tuberosum) fatiadas e minimamente processadas. Semina: Ciências Agrárias, v. 30, n. 3, 2009.

DAMODARAN, S.; PARKIN, K. L.; FENNEMA, O. R. (4th ed.). Fennema's food chemistry. CRC press, 2007. 
DENARDIN, C. C.; DA SILVA, L. P. Estrutura dos grânulos de amido e sua relação com propriedades físico-químicas. Ciência Rural, v. 39, n. 3, 2009.

DENG, L. et al. Characterization of gelatin/zein films fabricated by electrospinning vs solvent casting. Food Hydrocolloids, v. 74, p. 324-332, 1 jan. 2018.

DERRINGER, G.; SUICH, R. Simultaneous optimization of several response variables.Journal of Quality Technology, v. 12, p. 214-219, 1980.

DICKINSON, E. Stability and rheological implications of electrostatic milk protein - Polysaccharide interactions.Trends in Food Science and Technology, v. 9, n. 10, p. 347-354, 1 out. 1998.

DUFRESNE, A.; DUPEYRE, D.; VIGNON, M. R. Cellulose microfibrils from potato tuber cells: processing and characterization of starch-cellulose microfibril composites. Journal of Applied Polymer Science, v. 76, n. 14, p. 2080-2092, 2000.

ESWARANANDAM, S.; HETTIARACHCHY, N. S.; JOHNSON, M. G. Antimicrobial activity of citric, lactic, malic, or tartaric acids and nisin-incorporated soy protein film against Listeria monocytogenes, Escherichia coli O157: H7, and Salmonella gaminara. Journal of Food Science, v. 69, n. 3, 2004.

ETXABIDE, A. et al. Effect of cross-linking in surface properties and antioxidant activity of gelatin films incorporated with a curcumin derivative. Food Hydrocolloids, v. 66, p. 168-175, 1 maio 2017.

FABRA, M. J. et al. Antiviral and antioxidant properties of active alginate edible films containing phenolic extracts.Food Hydrocolloids, 23 fev. 2018.

FAKHOURI, F. M.; MARTELLI, S. M.; CAON, T.; VELASCO, J. I.; MEI, L. H. I. Edible films and coatings based on starch/gelatin: Film properties and effect of coatings on quality of refrigerated Red Crimson grapes. Postharvest Biology and Technology,v. 109, p. 57-64, 2015.

FAKHOURY, F. M. et al. Edible films made from blends of manioc starch and gelatin - Influence of different types of plasticizer and different levels of macromolecules on their properties. LWT - Food Science and Technology, v. 49, n. 1, p. 149-154, 1 nov. 2012. 
FANG, J. et al.The preparation and characterization of a series of chemically modified potato starches.Carbohydrate Polymers, v. 47, n. 3, p. 245-252, 15 fev. 2002.

FLORES, S. et al. Physical properties of tapioca-starch edible films: Influence of filmmaking and potassium sorbate. Food Research International, v. 40, n. 2, p. 257265, 1 mar. 2007.

FREUND, P. R.; WASHAM, C. J.; MAGGION, M. Natural color for use in foods. Cereal Foods World, v. 33, n. 7, p. 553-559, 1988.

GARAVAND, F. et al. Improving the integrity of natural biopolymer films used in food packaging by crosslinking approach: A review. International Journal of Biological Macromolecules, v. 104, p. 687-707, 2017.

GARCIA, Maria A.; MARTINO, Miriam N.; ZARITZKY, Noemi E. Microstructural Characterization of Plasticized Starch-Based Films. Starch-Stärke, v. 52, n. 4, p. 118-124, 2000.

GARCIA, Maria Pilar Montero et al. Edible Films and Coatings: Fundamentals and Applications. CRC Press, 2016, 616 p.

GHANBARZADEH, B.; ALMASI, H.; ENTEZAMI, A. A. Improving the barrier and mechanical properties of corn starch-based edible films: Effect of citric acid and carboxymethyl cellulose. Industrial Crops and Products, v. 33, n. 1, p. 229-235, 1 jan. 2011.

GIMÉNEZ, B.; MORENO, S., LÓPEZ-CABALLERO; M. E., MONTERO, P.; GÓMEZ-GUILLÉN, M. C. Antioxidant properties of green tea extract incorporated to fish gelatin films after simulated gastrointestinal enzymatic digestion. LWT - Food Science and Technology, v. 53(2), p. 445-451, 2013.

GOEL, A.; KUNNUMAKKARA, A. B.; AGGARWAL, B. B. Curcumin as "Curecumin": From kitchen to clinic. Biochemical Pharmacology, v. 75, n. 4, p. 787809, 15 fev. 2008. 
GÓMEZ-GUILLÉN, M. C. et al. Fish gelatin: a renewable material for developing active biodegradable films. Trends in Food Science \& Technology, v. 20, n. 1, p. 3-16, 1 jan. 2009.

GONTARD, N.; GUILBERT, S.; CUQ, J. L. Water and glycerol as plasticers affect mechanical and water vapor barrier properties of an edible wheat gluten film. Journal ofFoodScience, v. 53, n. 1, p. 206-211, 1992.

GOVINDARAJAN, V.S.Turmeric - chemistry, technology and quality. CRC Critical Reviews in Food Science and Nutrition, v. 12, n. 3, p.199 301,1980.

GUILBERT, S.; GONTARD, N.; CUQ, B. Technology and applications of edible protective films. Packaging Technology and Science, v. 8, n. 6, p. 339-346, 1995.

HANANI, Z. A. N. Gelatin. Encyclopedia of Food and Health, p. 191-195, 1 jan. 2016.

HANANI, Z. N.; ROOS, Y. H.; KERRY, J. P. Use and application of gelatin as potential biodegradable packaging materials for food products. International journal of biological macromolecules, v. 71, p. 94-102, 2014.

HENRIQUE, C. M.; CEREDA, M. P.; SARMENTO, S. B. S. Características físicas de filmes biodegradáveis produzidos a partir de amidos modificados de mandioca. Ciênc. Tecnol. Aliment., Campinas, v. 28, n. 1, p. 231-240, 2008.

HERTWIG, I.F. von. Plantas aromáticas e medicinais. São Paulo: Icone, 1986. Curcuma: p. 254-65.

HOWELER, R.; LUTALADIO, N.; THOMAS, G. Save and grow: cassava. A guide to sustainable production intensification. 129 p. FAO, 2013.

HRA ̌̌, A. R. et al. Comparison of antioxidative and synergistic effects of rosemary extract with $\alpha$-tocopherol, ascorbyl palmitate and citric acid in sunflower oil. Food Chemistry, v. 71, n. 2, p. 229-233, 1 nov. 2000.

HUNTERLAB.Measurement Methods, 2012.Disponível em: $<$ https://www.hunterlab.com/measurement-methods.html $>$. Acesso em : 30 ago. 2017. 
HUSSAIN, Z. et al. Exploring recent developments to improve antioxidant, antiinflammatory and antimicrobial efficacy of curcumin: A review of new trends and future perspectives. Materials Science and Engineering: C, v. 77, p. 1316-1326, 1 ago. 2017.

IBGE. SIDRA, Banco de tabelas estatísticas. [S.I.], 1995. Disponível em: $<$ https://sidra.ibge.gov.br/Tabela/523 > . Acesso em 12 jul. 2017.

IN, Ye-Won et al. Antimicrobial activities of acetic acid, citric acid and lactic acid against Shigella species. Journal of Food Safety, v. 33, n. 1, p. 79-85, 2013.

INDIRA PRIYADARSINI. Chemical and structural features influencing the biological activity of curcumin. Current pharmaceutical design, v. 19, n. 11, p. 20932100, 2013.

JARAMILLO, C. M. et al. Biodegradability and plasticizing effect of yerba mate extract on cassava starch edible films. Carbohydrate polymers, v. 151, p. 150-159, 2016.

JANSSON, A.; THUVANDER, F. Influence of thickness on the mechanical properties for starch films.Carbohydrate Polymers, v. 56, n. 4, p. 499-503, jul. 2004.

JONGJAREONRAK, A. et al. Characterization of edible films from skin gelatin of brownstripe red snapper and bigeye snapper. Food Hydrocolloids, v. 20, n. 4, p. 492$501,2006$.

KALAYCIOĞLU, Z. et al. Antimicrobial and physical properties of chitosan films incorporated with turmeric extract. International Journal of Biological Macromolecules, v. 101, p. 882-888, 1 ago. 2017.

$\mathrm{KCHAOU}, \mathrm{H}$. et al. Enhancement of structural, functional and antioxidant properties of fish gelatin films using Maillard reactions. Food Hydrocolloids, v. 83, p. 326-339, 1 out. 2018.

KEENAN, T. R. Gelatin. Polymer Science: A Comprehensive Reference, p. 237-247, 1 jan. 2012.

KIUCHI, F. et al. Nematocidal activity of turmeric: synergistic action of curcuminoids. Chemical and Pharmaceutical Bulletin, v. 41, n. 9, p. 1640-1643, 1993. 
KOLEV, Tsonko M. et al. DFT and experimental studies of the structure and vibrational spectra of curcumin. International Journal of Quantum Chemistry, v. 102, n. 6, p. 1069-1079, 2005.

KUMARI, M. et al. Development and structural characterization of edible films for improving fruit quality.Food Packaging and Shelf Life, v. 12, p. 42-50, 1 jun. 2017.

LEHNINGER, A. L.; NELSON, K. Y. Princípios de Bioquímica.4. ed. São Paulo: Sarvier, 2006. P 245-247, 529-530.

LI, L. et al. Development and characterization of irradiated-corn-starch films. Carbohydrate Polymers, v. 194, p. 395-400, 15 ago. 2018.

LIU, Y.; CAI, Y.; JIANG, X.; WU, J.; LE, X. Molecular interactions, characterization and antimicrobial activity of curcumin-chitosan blend films. Food Hydrocolloids,v. 52, p. 564-572, 2016.

LÓPEZ-CÓRDOBA, A. et al. Cassava starch films containing rosemary nanoparticles produced by solvent displacement method. Food Hydrocolloids, v. 71, p. 26-34, 1 out. 2017.

LUCHESE, C. L.; SPADA, J. C.; TESSARO, I. C. Starch content affects physicochemical properties of corn and cassava starch-based films. Industrial Crops and Products, v. 109, p. 619-626, 15 dez. 2017.

MA, Q.; REN, Y.; WANG, L. Investigation of antioxidant activity and release kinetics of curcumin from tara gum/ polyvinyl alcohol active film. Food Hydrocolloids, v. 70, p. 286-292, 1 set. 2017.

MA, X. et al. Properties of biodegradable citric acid-modified granular starch/thermoplastic pea starch composites. Carbohydrate Polymers, v. 75, n. 1, p. 18,5 jan. 2009.

MAIA, N.B.; BOVI, O.A.; DUARTE, F.R.; SORIA L. G.; ALMEIDA, J. R. Influência de tipos de rizomas de multiplicação no crescimento de Curcuma longa L. (Cúrcuma). Bragantia, Campinas, v. 54, n. 1, p. 33- 37,1995. 
MALI, S. et al. Effects of controlled storage on thermal, mechanical and barrier properties of plasticized films from different starch sources. Journal of Food Engineering, v. 75, n. 4, p. 453-460, 1 ago. 2006.

MANIGLIA, B. C. et al. Bioactive films based on babassu mesocarp flour and starch. Food Hydrocolloids, v. 70, p. 383-391, 1 set. 2017.

MANIGLIA, B. C. et al. Development of bioactive edible film from turmeric dye solvent extraction residue. LWT-Food Science and Technology, v. 56, n. 2, p. 269-277, 2014.

MANIGLIA, B. C. et al. Which plasticizer is suitable for films based on babassu starch isolated by different methods? Food Hydrocolloids, v. 89, p. 143-152, 1 abr. 2019.

MANIGLIA, B. C., DE PAULA, R. L., DOMINGOS, J. R., \& TAPIABLÁCIDO, D. R. Turmeric dye extraction residue for use in bioactive film production: Optimization of turmeric film plasticized with glycerol. LWT - Food Science and Technology, v. 64(2), p. 1187-1195, 2015.

MANIGLIA, Bianca Chieregato. Elaboração de filmes biodegradáveis a partir do resíduo da extração do pigmento de Cúrcuma. 2012. Dissertação de mestrado. Universidade de São Paulo.

MANI-LÓPEZ, E.; GARCÍA, H. S.; LÓPEZ-MALO, A. Organic acids as antimicrobials to control Salmonella in meat and poultry products.Food Research International, v. 45, n. 2, p. 713-721, 1 mar. 2012.

MANNERS, D. J.Recent developments in our understanding of amylopectin structure.Carbohydrate Polymers, v. 11, n. 2, p. 87-112, 1 jan. 1989.

MANOLOVA, Y. et al. The effect of the water on the curcumin tautomerism: A quantitative approach. Spectrochimica Acta - Part A: Molecular and Biomolecular Spectroscopy, v. 132, p. 815-820, 11 nov. 2014.

MANTOVAN, J. et al. Use of microbial levan in edible films based on cassava starch. Food Packaging and Shelf Life, v. 18, p. 31-36, 1 dez. 2018. 
MANZAN, A. C. C. M. et al. Extraction of essential oil and pigments from Curcuma longa [L.] by steam distillation and extraction with volatile solvents. Journal of Agricultural and Food Chemistry, v. 51, n. 23, p. 6802-6807, 2003.

MARGOLIN, W. FtsZ and the division of prokaryotic cells and organelles. Nature reviews Molecular cell biology, v. 6, n. 11, p. 862, 2005.

MARTINS, J. T.; CERQUEIRA, M. A.; VICENTE, A. Influence of -tocopherol on physicochemical properties of chitosan and based films.Food Hydrocolloids, v. 27, p. 220 -e $227,2012$.

MARTUCCI, J. F.; GENDE, L. B.; NEIRA, L. M.; RUSECKAITE, R. A. Oregano and lavender essential oils as antioxidant and antimicrobial additives of biogenic gelatin films. Industrial Crops and Products, v. 71, p. 205-213, 2015.

MCHUGH, T. H.; AVENA-BUSTILLOS, R.; KROCHTA, J. M. Hydrophilic edible films: modified procedure for water vapor permeability and explanation of thickness effects. Journal of food science, v. 58, n. 4, p. 899-903, 1993.

MILAN, D.R. Cúrcuma produção e utilização como ingrediente na indústria de alimentos. Revista Brasileira de Corantes Naturais,v. 1, n. 1, p. 248 -249, 1992.

MILES, M. J. et al. The roles of amylose and amylopectin in the gelation and retrogradation of starch. Carbohydrate Research, v. 135, n. 2, p. 271-281, 15 jan. 1985.

MILLER, K. S., KROCHTA, J. M. Oxygen and aroma barrier properties of edible films: a review. Food Science and Technology, v. 8, n. 7, p. 228-237, Jul., 1997.

MONIER-WILliAMS, M. A Sanskrit-English Dictionary, Motilal Banarsidass Publishers Pvt, New Delhi, 1997.

MORENO, O. et al. Influence of starch oxidation on the functionality of starchgelatin based active films. Carbohydrate Polymers, v. 178, p. 147-158, 15 dez. 2017.

MORENO, O.; ATARÉS, L.; CHIRALT, A. Effect of the incorporation of antimicrobial/antioxidant proteins on the properties of potato starch films. Carbohydrate Polymers, v. 133, p. 353-364, 20 nov. 2015. 
MUSSO, Y. S.; SALGADO, P. R.; MAURI, A. N. Smart edible films based on gelatin and curcumin. Food Hydrocolloids, v. 66, p. 8-15, 1 maio 2017.

NAGARAJAN, M. et al. Characteristics of bio-nanocomposite films from tilapia skin gelatin incorporated with hydrophilic and hydrophobic nanoclays. Journal of Food Engineering, v. 143, p. 195-204, 1 dez. 2014.

NALLASAMY, P.; MOHAN, S. Vibrational spectra of cis-1, 4polyisoprene. Arabian Journal for Science and Engineering, v. 29, n. 1; PART A, p. 17-26, 2004.

NELSON, D. L.; COX, Michael M. ( $4^{\text {th }}$ ed. $)$. Lehninger princípios de bioquímica. SARVIER, 2006.

NIKOLAUS, B. E.; WAYMAN, B. E.; ENCINAS, E.The bactericidal effect of citric acid and sodium hypochlorite on anaerobic bacteria.J Endod, v. 14, n. 1, p. 31-34, 1 jan. 1988.

NILSUWAN, K.; BENJAKUL, S.; PRODPRAN, T. Properties and antioxidative activity of fish gelatin-based film incorporated with epigallocatechin gallate. Food Hydrocolloids, v. 80, p. 212-221, 1 jul. 2018.

NUNES, Y. L. Preparação e caracterização de bioblendas poliméricas a partir de gelatina bovina e de tilápia com amido de milho. 2014. Universidade Federal do Rio Grande do Norte, Natal. Dissertação de mestrado.

NUR HANANI, Z. A. et al. Development and characterization of biodegradable composite films based on gelatin derived from beef, pork and fish sources. Foods, v. 2, n. 1, p. 1-17, 2013.

NUR HANANI, Z. A.; ROOS, Y. H.; KERRY, J. P. Use and application of gelatin as potential biodegradable packaging materials for food products. International Journal of Biological Macromolecules, v. 71, p. 94-102, 2014.

OLSSON, E. et al. The effect of $\mathrm{pH}$ on hydrolysis, cross-linking and barrier properties of starch barriers containing citric acid. Carbohydrate Polymers, v. 98, n. 2, p. $1505-1513,6$ nov. 2013. 
PANCHAROEN, O.; PRAWAT, U.; TUNTIWACHWUTTIKUL, P. Phytochemistry of the zingiberaceae.Studies in Natural Products Chemistry, v. 23, p. 797-865, 2000.

PAPAGIANNI, M. Advances in citric acid fermentation by Aspergillus niger: biochemical aspects, membrane transport and modeling. Biotechnology advances, v. 25, n. 3, p. 244-263, 2007.

PÉREZ, L. M.; PICCIRILLI, G. N.; DELORENZI, N. J.; VERDINI, R. A. Effect of different combinations of glycerol and/or trehalose on physical and structural properties of whey protein concentrate-based edible films. Food Hydrocolloids, v. 56,p. $352-359,2016$.

PIÑEROS-HERNANDEZ， D.; MEDINA-JARAMILLO， C.; LÓPEZCÓRDOBA, A.; GOYANES, S. Edible cassava starch films carrying rosemary antioxidant extracts for potential use as active food packaging. Food Hydrocolloids, v. 63, p. 488-495, 2017.

PODSHIVALOV, A. et al. Gelatin/potato starch edible biocomposite films: Correlation between morphology and physical properties. Carbohydrate Polymers, v. 157, p. 1162-1172, 10 fev. 2017.

PRASAD, S.; GUPTA, S. C. TYAGI; A. K. AGGARWAL, B. B. Curcumin, a component of golden spice: from bedside to bench and back. BiotechnologyAdvances, v. 32, n. 6, p. 1053-1064, 2014.

RAI, D. et al. Curcumin inhibits FtsZ assembly: an attractive mechanism for its antibacterial activity. Biochemical Journal, v. 410, n. 1, p. 147-155, 2008.

RAMÍREZ, C. et al. Study of contact angle, wettability and water vapor permeability in carboxymethylcellulose (CMC) based film with murta leaves (Ugni molinae Turcz) extract. Journal of Food Engineering, v. 109, n. 3, p. 424-429, 1 abr. 2012.

RAMIREZ, D. O. S. et al. Wool keratin film plasticized by citric acid for food packaging. Food Packaging and Shelf Life, v. 12, p. 100-106, 1 jun. 2017. 
RAVINDRAN, P.N. Turmeric-the golden spice of life. Turmeric: The genus Curcuma.Taylor and Francis Group, p. 1-14, 2006.

REDDY, N.; YANG, Y. Citric acid cross-linking of starch films.Food Chemistry, v. 118, n. 3, p. 702-711, 2010.

RIVERO, S.; GARCÍA, M. A.; PINOTTI, A. Correlations between structural, barrier, thermal and mechanical properties of plasticized gelatin films. Innovative Food Science \& Emerging Technologies, v. 11, n. 2, p. 369-375, 1 abr. 2010.

RUFINO, M. S. M; ALVES, R. E.; BRITO, E. S.; MORAIS, S. M.; SAMPAIO, C. G.; PÉREZ-JIMÉNEZ, J.; SAURA-CALIXTO, F. D. Metodologia Científica:

Determinação da Atividade Antioxidante Total em Frutas pela Captura do Radical Livre $\mathrm{ABST}^{+}$. Comunicado técnico on line. EMBRAPA, ISSN 1679-6535, Fortaleza, CE, 2007.

SANTOS, A. B.; OLIVEIRA, S. P. Utilização do açafrão (Curcuma longa L.) como corante natural para alimentos. Boletim da SBTA, Campinas, v.2, n. 25, p. 90, 1991.

SCARTEZZINI, P.; SPERONI, E. Review on some plants of Indian traditional medicine with antioxidant activity.Journal of Ethnopharmacology, v. 71, n. 1 e 2, p. 23-43, jul. 2000.

SEGTNAN, V. et al. Rapid assessment of physico-chemical properties of gelatine using near infrared spectroscopy.Food Hydrocolloids, v. 17, n. 5, p. 585-592, 1 set. 2003.

SELIGRA, P. G. et al. Biodegradable and non-retrogradable eco-films based on starch-glycerol with citric acid as crosslinking agent.Carbohydrate Polymers, v. 138, p. 66-74, 15 mar. 2016.

SHAHIDI, F.; ARACHCHI, J. K. V.; JEON, Y.-J.Food applications of chitin and chitosans.Trends in Food Science \& Technology, v. 10, n. 2, p. 37-51, 1 fev. 1999. 
SHI, R. et al. The effect of citric acid on the structural properties and cytotoxicity of the polyvinyl alcohol/starch films when molding at high temperature. Carbohydrate Polymers, v. 74, n. 4, p. 763-770, 21 nov. 2008.

SHUJUN, W.; JINGLIN, Y.; WENYUAN, G. Use of X-ray diffractometry for identification of different Fritillaria traditional Chinese medicine. Trends Applied Sci. Res, v. 1, p. 334-340, 2006.

SIGMA-ALDRICH. IR Spectrum Table \& $\quad$ Chart. $<$ https://www.sigmaaldrich.com/technical-documents/articles/biology/ir-spectrumtable.html >. Acesso em 2. dez. 2018.

SILVA, A. C. DA et al. Impact of curcumin nanoformulation on its antimicrobial activity. Trends in Food Science \& Technology, v. 72, p. 74-82, 1 fev. 2018.

SINGER APLEVICZ, K.; DEMIATE, I. M. Caracterização de amidos de mandioca nativos e modificados e utilização em produtos panificados. Ciência e Tecnologia de Alimentos, v. 27, n. 3, 2007.

SINTHUSAMRAN, S. et al. Characteristics and properties of gelatin from seabass (Lates calcarifer) swim bladder: impact of extraction temperatures. Waste and Biomass Valorization, v. 9, n. 2, p. 315-325, 2018.

SIRIRUGSA, P.; LARSEN, K.; MAKNOI, C. The genus Curcuma L.(zingiberaceae): distribution and classification with reference to species diversity in Thailand. Gardens' Bulletin Singapore, v. 59, p. 203-320, 2007.

SIVIERO, A. et al. Curcumin, a golden spice with a low bioavailability. Journal of Herbal Medicine, v. 5, n. 2, p. 57-70, 1 jun. 2015.

SOBRAL, P. J. A. Propriedades funcionais de biofilmes de gelatina em função da espessura. Ciência e Engenharia, v.8, n.1, p.60-67, 1999.

SOBRAL, P. J. A.; MONTERREY-QUINTERO, E. S.; HABITANTE, A. M. Q. B.Glass transition of Nile tilapia myofibrillar protein films plasticized by glycerin and water. Journal of Thermal Analysis and Calorimetry, v. 67 n. 2, 499-504, 2002. 
SOCRATES, G. Infrared Characteristic Group Frequencies: tables and charts. John Wiley \& Sons, 1994.

STEINBÜCHEL, A.; RHEE, S. K. Polysaccharides and polyamides in the food industry: properties, production, and patents. Wiley-VCH Verlag $\mathrm{GmbH} \& \mathrm{CO}$. KGaA, v.1, 2005.

SU, H. C. F.; ROBERT, H.; JILANE, G. Isolation and characterization of insect repellents from turmeric.Journal of Agriculture and Food Chemistry, v. 30, p. 290 $292,1982$.

SUDERMAN, N.; ISA, M. I. N.; SARBON, N. M. The effect of plasticizers on the functional properties of biodegradable gelatin-based film: A review. Food Bioscience, v. 24, p. 111-119, 1 ago. 2018.

SUETH-SANTIAGO, V. et al. Curcumina, o pó dourado do açafrão-da-terra: introspecções sobre química e atividades biológicas. Química Nova, v. 38, n. 4, p. 538$552,2015$.

SUPPAKUL, P.; BOONLERT, R.; BUAPHET, W.; SONKAEW, P.; LUCKANATINVONG, V. Efficacy of superior antioxidant Indian gooseberry extractincorporated edible Indian gooseberry puree/methylcellulose composite films on enhancing the shelf life of roasted cashew nut. Food Control, v. 69, p. 51-60, 2016.

TAPIA-BLÁCIDO, D. R.; SOBRAL, P. J. D. A.; MENEGALLI, F. C. Effect of drying conditions and plasticizer type on some physical and mechanical properties of amaranth flour films. LWT - Food Science and Technology, v. 50, n. 2, p. 392-400, 1 mar. 2013.

TESTER, R. F.; KARKALAS, J.; QI, X. Starch—composition, fine structure and architecture. Journal of cereal Science, v. 39, n. 2, p. 151-165, 2004.

TILLET, G.; BOUTEVIN, B.; AMEDURI, B. Chemical reactions of polymer crosslinking and post-crosslinking at room and medium temperature.Progress in Polymer Science (Oxford), v. 36, n. 2, p. 191-217, 1 fev. 2011. 
TOLEDO, E. M. Estudo das propriedades estruturais da curcumina no vácuo usando dinâmica molecular de Car-Parrinello, 2013. Dissertação de Mestrado. Universidade Estadual de Goiás, Anápolis.

TONGDEESOONTORN, W. et al. Mechanical and physical properties of cassava starch-gelatin composite films. International Journal of Polymeric Materials, v. 61, n. 10, p. 778-792, 2012.

TONGNUANCHAN, P.; BENJAKUL, S.; PRODPRAN, T. Physico-chemical properties, morphology and antioxidant activity of film from fish skin gelatin incorporated with root essential oils. Journal of Food Engineering, v. 117, n. 3, p. 350360, 1 ago. 2013.

TONUKARI, N. J. Cassava and the future of starch. Electronic journal of biotechnology, v. 7, n. 1, p. 5-8, 2004.

URANGA, J. et al. Cross-linking of fish gelatins to develop sustainable films with enhanced properties. European Polymer Journal, v. 78, p. 82-90, 1 maio 2016.

VAN SOEST, J. J. G.; VLIEGENTHART, J. F. G. Crystallinity in starch plastics: consequences for material properties. Trends in Biotechnology, v. 15, n. 6, p. 208-213, 1 jun. 1997.

VANDENBERGHE, L. P. S. et al. Production and Application of Citric Acid. In: Current Developments in Biotechnology and Bioengineering. [s.1.]Elsevier, 2017. p. $557-575$.

VIASAN, A. C.; NIRMALAMENON, A.; MADHUSUDHANA RAO, J.; NARAYANAN, C. S.; MATHEWS, A. G. Chemical analysis os some cultivars of Curcuma longa Linn. Journal of Food Science, v. 26, n. 5, p.293 - 295, 1989.

VIUDA-MARTOS, M. et al.In vitro antioxidant and antibacterial activities of essentials oils obtained from Egyptian aromatic plants. Food Control, v. 22, n. 11, p. 1715-1722, 1 nov. 2011. 
WANG, J. et al. Sulfated modification, characterization and structure-antioxidant relationships of Artemisia sphaerocephala polysaccharides.Carbohydrate Polymers, v. 81, n. 4, p. 897-905, 23 jul. 2010.

WANG, K.; HENRY, R. J.; GILBERT, R. G. Causal relations among starch biosynthesis, structure, and properties. Springer Science Reviews, v. 2, n. 1-2, p. 15-33, 2014.

WANG, L. Z. et al. Assessment of film-forming potential and properties of protein and polysaccharide-based biopolymer films. International journal of food science \& technology, v. 42, n. 9, p. 1128-1138, 2007.

WANG, W. et al. Performance of high amylose starch-composited gelatin films influenced by gelatinization and concentration. International Journal of Biological Macromolecules, v. 94, p. 258-265, 1 jan. 2017.

WARREN, F. J.; GIDLEY, M. J.; FLANAGAN, B. M. Infrared spectroscopy as a tool to characterise starch ordered structure - a joint FTIR-ATR, NMR, XRD and DSC study. Carbohydrate Polymers, v. 139, p. 35-42, 30 mar. 2016.

XU, X.Y.; KIM, K.M.; HANNA, M.A.; NAG, D. Chitosan-starch composite film: preparation and characterization. Industrial Crops and Products an International Journal, v. 21, p. 85-192, 2005.

YANG, H.; WEN, X. L., GUO; S. g.; CHEN, M. t.; JIANG, A. m.; LAI, L. S. Physical, antioxidant and structural characterization of blend films based on hsian-tsao gum (HG) and casein (CAS). Carbohydrate Polymers, v. 134, p. 222-229, 2015.

ZHANG, N.; LIU, H.; YU, L.; LIU, X.;ZHANG, L.; CHEN, L.; SHANKS, R. Developing gelatin-starch blends for use as capsule materials. Carbohydrate Polymers, v. 92, p. 455-461, 2013.

ZHONG, Q.; XIA, W. Physicochemical properties of edible and preservative films from chitosan/cassava starch/gelatin blend plasticized with glycerol. Food Technology and Biotechnology, v. 46, n. 3, p. 262-269, 2008. 